\title{
Mobilization of reserves and vigor of soybean seeds under desiccation with glufosinate ammonium ${ }^{1}$
}

\author{
Carolina Maria Luzia Delgado ${ }^{2}$, Cileide Maria Medeiros de Coelho ${ }^{2 *}$ \\ Gesieli Priscila Buba ${ }^{2}$
}

\begin{abstract}
The physiological quality of seeds depends on the cellular organization and their capacity to mobilize reserves. The goal of this study was to assess the germination and vigor of soybeans seeds of Benso1RR and NA 5909 RG cultivars from desiccated plants or not, by mobilizing reserves. Cultivars from desiccated plants or not, by mobilizing reserves. The plants were desiccated with glufosinate ammonium (GLA) in reproductive stage R7.1 or not (TST). The physiological seed quality was assessed by germination tests, accelerated aging and seedling length. For the mobilization of reserves were assessed within 48 hours of soaking: phytate, protein and soluble sugar contents. In 48 hours of soaking, seeds from desiccated plants in cultivar NA 5909 RG showed lower mobilization of soluble protein and soluble sugar, reflecting low vigor seedlings compared to their controls. For cultivar Benso1RR, in 48 hours of soaking, the application of GLA did not affect the mobilization of soluble protein when compared to control and did not differ as to vigor. It is concluded that the use of the desiccant has negatively influenced the mobilization of soluble protein and soluble sugar for cultivar NA 5909 RG, reflecting a low percentage of germination and low vigor.
\end{abstract}

Index terms: vigor, herbicide, protein, soluble sugar.

\section{Mobilização de reservas e vigor de sementes de soja sob dessecação com glufosinato de amônio}

\begin{abstract}
RESUMO - A qualidade fisiológica em sementes depende da organização celular e da sua capacidade de mobilização de reservas. O objetivo do trabalho foi avaliar a germinação e vigor das sementes de soja das cultivares Benso1RR e NA 5909 RG proveniente de plantas dessecadas ou não, através da mobilização de reservas. As plantas foram dessecadas com glufosinato de amônio (GLA) no estádio reprodutivo R7.1 ou não (TST). A qualidade fisiológica das sementes foi avaliada através dos testes de germinação, envelhecimento acelerado e comprimento de plântula. Para a mobilização de reservas foram avaliados em até 48 h de embebição, teores de fitato, proteína e açúcar solúvel. Em 48 h de embebição sementes provenientes de plantas dessecadas da cultivar NA 5909 RG apresentaram menor mobilização de proteína solúvel e açúcar solúvel refletindo em plântulas de baixo vigor em relação a sua testemunha. Para a cultivar Benso1RR em 48 h de embebição, a aplicação do GLA não afetou a mobilização de proteína solúvel quando comparada à testemunha, não diferindo quanto ao vigor. Conclui-se que a utilização do dessecante influenciou negativamente na mobilização de proteína solúvel e açúcar solúvel para a cultivar NA 5909 RG refletindo em baixo percentual de germinação e baixo vigor.
\end{abstract}

Termos para indexação: vigor, herbicida, proteína, açúcar solúvel.

\section{Introduction}

The soybean seeds period of stay in the field after physiological maturity is crucial in the deterioration, influencing the fall of vigor. An alternative to prevent the seeds from remaining in the field after reaching physiological maturity is the application of herbicides aiming to quickly desiccate the plant, bringing forward its seeds harvest. Thus, application of the desiccant becomes an important factor to maintain the seed physiological quality.

The seeds physiological quality depends on the cellular organization and reserves mobilization capacity for the formation of more vigorous seedlings. According to Henning et al. (2010) and Pereira et al. (2015) more vigorous soybean seeds have higher soluble protein, starch and soluble sugars contents as well as higher reserves mobilization capacity

${ }^{1}$ Submitted on $04 / 13 / 2015$. Accepted for publication on 05/29/2015.

${ }^{2}$ Centro de Ciências Agroveterinárias, Universidade do Estado de Santa Catarina Luiz de Camões, 88520-000 - Lages, SC, Brasil.

*Corresponding author <cileide.souza@udesc.br> 
during germination, resulting in soybean seedlings with better initial performance.

Currently several studies have been relating desiccant use with seeds final quality, where the herbicide mode of action, weather conditions and phenological stage in which the plant is found may maintain or negatively affect the seeds quality, and even not bring forward the harvest. According to Guimarães et al. (2012) the glufosinate ammonium herbicide reduces soybean seed germination when applied in the R6 stage and the herbicide paraquat promotes the best seeds germination rates and vigor when used in stages R6 and R7.2. Pinto et al. (2014) have found that desiccation with glufosinate ammonium in bean seeds had a lower percentage of normal seedlings in the germination test, accelerated aging and first count.

Glufosinate ammonium is a contact herbicide, with the ability to move at a short distance. Its mode of action inhibits the enzyme glutamine synthetase (GS) blocking glutamine synthesis via glutamate and thus the assimilation of $\mathrm{NH}_{4}^{+}$, which is accumulated in the plants leaves (Carvalho, 2013). According to the same author, glufosinate ammonium might still affect the synthesis of some amino acids, production of free radicals and blocking photosynthesis, leading to plant death. However, few studies report what changes occur in the reserve components during germination in seeds from plants desiccated with the herbicide.

The seeds germination process corresponds to three stages; initially, the first stage of water absorption, which occurs quickly and passively; afterwards, the second stage, which is characterized by delayed water absorption; and the third phase, where again the seeds begin to absorb water quickly (Teulat-Merah et al., 2011; Weitbrecht et al., 2011)

From the precise moment when each of the three stages starts and ends in the germination process of soybean seeds, it becomes easier to infer the possible effects of desiccant application in soybean plants in reproductive stage R7.1, on the seeds physiological quality and their subsequent effect on the germination process and vigor.

In this sense, the objective of this study was to assess the germination and vigor of soybean cultivars Benso1RR and NA 5909 RG by mobilizing reserves during the germination process from desiccated plants or not, with glufosinate ammonium (GLA) in reproductive stage R7.1 (preharvest).

\section{Material and Methods}

The seeds used in the experiment are from the 2012/2013 harvest, derived from plants desiccated or not with glufosinate ammonium in stage R7.1 (Ritchie et al., 1982). The work sample was performed according to Regras para Análise de
Sementes (Rules for Seed Analysis) (Brasil, 2009).

The seeds physiological quality was assessed by the germination percentage, seedling length and accelerated aging test. The reserves mobilization during germination (phytate, sugar and soluble protein) was determined in soaking times $0 \mathrm{~h}, 3 \mathrm{~h}, 6 \mathrm{~h}, 16 \mathrm{~h}, 24 \mathrm{~h}$ and $48 \mathrm{~h}$, characterizing the soaking three-phase pattern.

The germination test consisted of four subsamples of 50 seeds, germinated between three sheets of germitest paper, moistened with distilled water 2.5 times the weight of the paper. The rolls with the seeds remained in germination at $25{ }^{\circ} \mathrm{C}$ temperature. Assessments were performed on the fifth day, considering only normal seedlings, according to Brasil (2009).

To assess the seedlings length, the methodology proposed by Nakagawa (1999) was used. Assessments were performed five days after sowing, by measuring the total length of normal seedlings with the help of a caliper. The results were expressed in centimeters.

For assessment of seed vigor, accelerated aging test was conducted, in which four subsamples of 50 seeds for each treatment were used. Seeds were distributed on aluminum screens fixed on the inside of plastic boxes and $40 \mathrm{~mL}$ of water were added. The boxes were closed and kept in an aging chamber for $48 \mathrm{~h}$ at $42^{\circ} \mathrm{C}$, according to Marcos-Filho (1999). After this period, the seeds were germinated at $25^{\circ} \mathrm{C}$ and on the fifth day after the test installation normal seedlings counting was carried out, as in the germination test.

The soaking curve was obtained according to Ma et al. (2004) and Han et al. (2013) with some adjustments. For each soaking time, two replicates with 50 seeds on roll paper were used, which was formed using three sheets of germitest paper by repetition. The paper was moistened with distilled water (2.5 times the weight of the paper) and the rolls were taken to the germinator in a vertical position at $25^{\circ} \mathrm{C}, \mathrm{C}$ in the presence of natural light, remaining for $3 \mathrm{~h}, 6 \mathrm{~h}, 16 \mathrm{~h}, 24 \mathrm{~h}$ and $48 \mathrm{~h}$. At each time, a sample of $5 \mathrm{~g}$ of seeds was taken and dried at $105^{\circ} \mathrm{C}$ for $24 \mathrm{~h}$ to determine moisture. By means of the moisture difference between the times, the soaking curve was obtained. The moment the radicle protrusion reached $50 \%+1$ was considered the end of phase II and the beginning of phase III.

Phytate content was determined by the method of Latta and Eskin (1980), which is based on the formation of an ironsulfosalicylic acid compound of dark blue staining (Wade reagent). In the presence of phytate, iron is sequestered and becomes unavailable to react with sulfosalicylic acid, which results in decreased color intensity. Readings were taken in a spectrophotometer at each time of the soaking curve, and three repetitions were performed at each time.

For soluble protein analysis, three replicates were 
performed with $1 \mathrm{~g}$ of soybean seed from all selected points of the soaking curve. The samples were ground in liquid nitrogen to form a flour. The material was homogenized in $10 \mathrm{mM}$ potassium phosphate buffer $(\mathrm{pH}$ 7.5) containing 1 $\mathrm{mM}$ of EDTA (Ethylenediamine tetra acetic acid, widely abbreviated as EDTA (ethylenediamine tetra acetic acid), 3 mM of DTT (dithiothreitol) and about $4 \%$ of PVPP (polyvinyl polypyrrolidone), according to Azevedo et al. (1998) and Garcia et al. (2006). The homogenate was centrifuged at 3500 rpm for 30 minutes. The total soluble proteins were determined in a spectrophotometer according to the method described by Bradford (1976) and results were expressed in mg. $\mathrm{g}^{-1}$ of seeds dry weight.

For total soluble sugar analysis, samples of $0.250 \mathrm{~g}$ of dried and ground seeds of each point of the soaking curve were weighed. The total soluble sugars were determined by the Antrona method, according to Clegg (1956) and the samples reading was done with a spectrophotometer at a wavelength of $620 \mathrm{~nm}$. The results were expressed in $\mathrm{mg} . \mathrm{g}^{-1}$ of seeds dry weight.

To verify the normal data distribution, the Shapiro-Wilk test $(5 \%)$ was used; for the homogeneity of variance, the Cochran and Barlett (5\%) test was used; and the germination percentage was transformed into sine arc of $(\mathrm{x} / 100)^{0.5}$. Next, the data were submitted to analysis of variance by the $\mathrm{F}$ test. For analysis of seed physiological quality and initial content of biochemical components, the Tukey test at $5 \%$ error probability was used and for the analysis of reserves mobilization over time, regression analysis was used. Analyses were performed via $\mathrm{SAS}^{\circledR}(\mathrm{SAS}, 2009)$ computer program.

\section{Results and Discussion}

Comparing the vigor of the two varieties of seeds from non-desiccated plants (Table 1) it was possible to observe, by the accelerated aging test, that seeds of cultivar NA 5909 RG showed superior vigor, with $89 \%$ of normal seedlings and $19 \mathrm{~cm}$ in length, compared to seeds of cultivar Benso1RR, which showed $79 \%$ of normal seedlings and $16 \mathrm{~cm}$ in length (Table 1). Desiccation did not affect the seed vigor of cultivar Benso1RR compared to its control (Table 1).

Table 1. Physiological quality of soybean seeds of two cultivars from plants desiccated with glufosinate ammonium (GLA) or not (TST) in reproductive stage R7.1.

\begin{tabular}{|c|c|c|c|c|c|}
\hline & $\begin{array}{c}\text { NA } 5909 \text { RG } \\
\text { TST } \\
\text { High vigor }\end{array}$ & $\begin{array}{c}\text { NA } 5909 \text { RG } \\
\text { GLA } \\
\text { Low Vigor }\end{array}$ & $\begin{array}{c}\text { BENSO1RR } \\
\text { TST } \\
\text { High vigor }\end{array}$ & $\begin{array}{c}\text { BENSO1RR } \\
\text { GLA } \\
\text { High vigor }\end{array}$ & $\begin{array}{l}\mathrm{CV} \\
(\%)\end{array}$ \\
\hline Germination (\%) & $92 \mathrm{a}$ & $79 \mathrm{~b}$ & $94 \mathrm{a}$ & $89 \mathrm{a}$ & 3.58 \\
\hline AA $(\%)$ & $89 a$ & $81 \mathrm{~b}$ & $79 \mathrm{~b}$ & $82 \mathrm{~b}$ & 3.35 \\
\hline $\mathrm{SL}(\mathrm{cm})$ & $19.18 \mathrm{a}$ & $17 \mathrm{~b}$ & $17.06 \mathrm{~b}$ & $18.44 \mathrm{ab}$ & 2.10 \\
\hline
\end{tabular}

On the row, the means followed by the same letter do not differ at $5 \%$ by Tukey test.

$\mathrm{SL}$ - seedling length; AA - accelerated aging.

The seeds from desiccated plants of cultivar NA 5909 RG were negatively impacted by the application of glufosinate ammonium, with low vigor, lower germination percentage (79\%) and lower seedling length $(17 \mathrm{~cm})$ compared to control. Similar results have already been observed previously in the literature, indicating the low herbicide efficiency in obtaining seeds with high physiological quality, promoting low percentage of germination and low vigor (Guimarães et al., 2012; Lacerda et al., 2005a; Pinto et al., 2014).

During the soaking process, it was observed that the application of glufosinate ammonium had changed the pattern of water absorption of cultivar Benso1RR within $48 \mathrm{~h}$, extending phase II (Figure 1), allowing for more time to repair the seeds cellular structures and allocation of their reserves, which may have contributed to maintaining the cultivar vigor on the application of desiccant. This same change in soaking pattern was not observed for seeds of cultivar NA 5909 RG from desiccated plants, which presented low vigor.

Within 24 hours of soaking, all treatments showed radicle protrusion, with water content in the seeds close to $60 \%$, coinciding with Mengarda et al. (2015) and Castro et al. (2004) who have reported that at the end of phase II during germination, the seeds water content is close to $60 \%$, starting phase III, when root protrusion starts. Han et al. (2013) have defined that phase II is between $12 \mathrm{~h}$ and $24 \mathrm{~h}$ of soaking in soybean seeds.

Also in 24 hours of soaking, desiccated seeds from plants of cultivar NA 5909 RG showed $28 \%$ of root protrusion and their control showed $68 \%$. For cultivar Benso1RR from desiccated plants there were $42 \%$ of root protrusion and its control $67 \%$ (Figure 2). This delay in the root protrusion process could be an advantage from the point of view of tolerance to some sort of stress that might occur in the field, as only few seeds would be affected, since not all would issue sprouts during stress. 


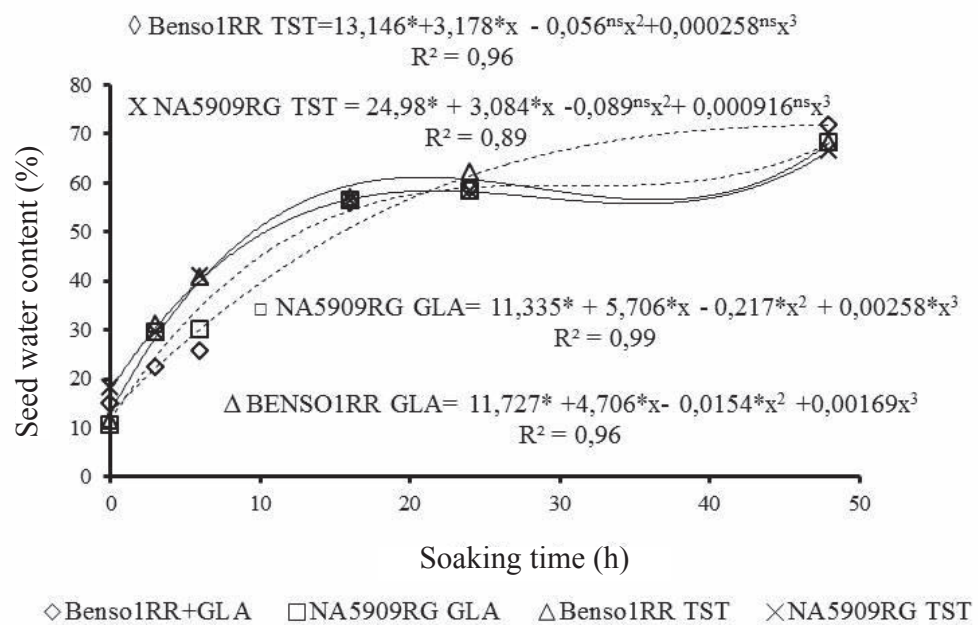

Figure 1. Soybean seeds soaking three-phase pattern for cultivars NA 5909 RG and Benso1RR from plants that were desiccated with glufosinate ammonium (GLA) and non-desiccated (TST).

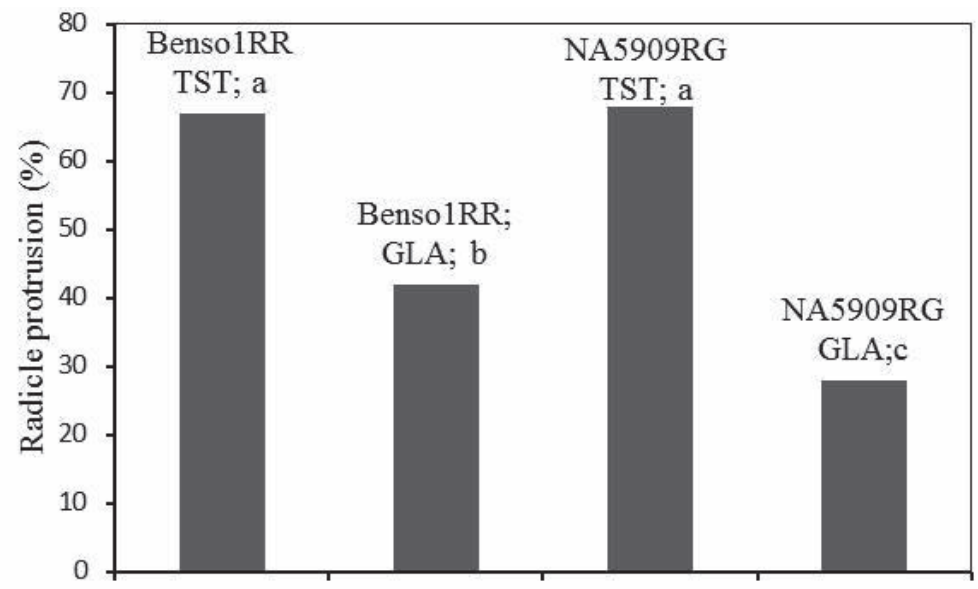

Figure 2. Radicle protrusion from soybean seeds of cultivars NA 5909 RG and Benso1RR from desiccated plants with glufosinate ammonium (GLA) or not (TST). Means followed by the same letter do not differ at $5 \%$ by Tukey test.

In $48 \mathrm{~h}$ of soaking, seeds from desiccated plants reached almost the same percentage (100\%) of root protrusion compared to their controls (Figure 2), indicating the start of phase III. Similar data for soybeans and beans seeds have been observed, and phase III occurs at 40 hours of soaking for soybeans seeds and at $30 \mathrm{~h}$ for beans seeds (Teulat-Merah et al., 2011; Cheng et al., 2009).

Regarding the biochemical components of dry seeds reserves, it was observed that the initial phytate and soluble protein content did not change with the application of glufosinate ammonium, when compared with their controls, but there was a reduction of the initial levels of soluble sugar for cultivars NA 5909 RG and Benso1RR (Table 2) regarding their controls. A similar result was observed by Lacerda et al. (2003b), who have not observed differences in total protein content when comparing seeds from plants desiccated with glufosinate ammonium compared to control in different reproductive stages of soybeans. However, they have noted significant differences in the ether extract (lipid) between seeds from desiccated plants in relation to their controls, and, the later the product was applied, the more the ether extract content approached the control.

Phytate is the main storage form of phosphorus in seeds, and can be used as energy reserve, besides being a major precursor of polysaccharides constituting cell walls (Scott, 1991). The initial phytate content of seeds from desiccated plants of cultivars NA 5909 RG and Benso1RR were similar when compared with seeds from non-desiccated plants, ranging from 1.27 to 1.97 mg. $\mathrm{g}^{-1}$ of seeds. The levels observed by Moreira et al. (2012) ranged between 1.131 and $2.43 \mathrm{~g} .100 \mathrm{~g}^{-1}$. 
Table 2. Initial content of biochemical components in soybean seeds from plants desiccated with glufosinate ammonium (GLA) or not (TST).

\begin{tabular}{cccc}
\hline Treatments & Soluble protein $\left(\mathrm{mg}^{-1} \mathrm{~g}^{-1}\right)$ & Soluble sugar $\left(\mathrm{mg} \cdot \mathrm{g}^{-1}\right)$ & Phytate $\left(\mathrm{mg} . \mathrm{g}^{-1}\right)$ \\
\hline NA 5909 RG TST & $101.54 \mathrm{a}$ & $142.3098 \mathrm{a}$ & $1.58 \mathrm{a}$ \\
NA 5909 RG + GLA & $104.26 \mathrm{a}$ & $100.8929 \mathrm{ab}$ & $1.57 \mathrm{a}$ \\
Benso1RR TST & $110.11 \mathrm{a}$ & $94.69 \mathrm{~b}$ & $1.27 \mathrm{a}$ \\
Benso1RR + GLA & $109.67 \mathrm{a}$ & $81.65 \mathrm{~b}$ & $1.98 \mathrm{a}$ \\
\hline CV $(\%)$ & 3.96 & 16.73 & 13.76 \\
\hline
\end{tabular}

In the column, means followed by the same letter do not differ at $5 \%$ by Tukey test.

The initial content of soluble protein for cultivar NA 5909 RG was $104.26 \mathrm{mg} . \mathrm{g}^{-1}$, being similar for cultivar Benso1RR, with a content of $110.11 \mathrm{mg} \cdot \mathrm{g}^{-1}$, being close to the value found by Stajner et al. (2007) who have observed $95 \mathrm{mg} . \mathrm{g}^{-}$ ${ }^{1}$ of soluble protein in soybean seeds, and the authors have not observed any changes when different $\gamma$ radiation dosages were applied to the seeds, and no difference was observed in the soluble protein contents of this study among the seeds from desiccated plants regarding their control (Table 1).

The application of desiccant promoted the reduction of the initial soluble sugar content in seeds for the two cultivars in relation to their controls (Table 2). For cultivar NA 5909

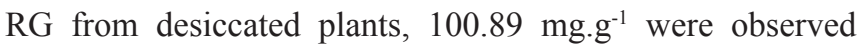
and their control $142.30 \mathrm{mg} . \mathrm{g}^{-1}$. For cultivar Benso1RR from desiccated plants, $81.65 \mathrm{mg} . \mathrm{g}^{-1}$ were observed and their control $94.69 \mathrm{mg} . \mathrm{g}^{-1}$. The values found in this study are similar to those found by Obendorf et al. (2009) who observed between 100 and $150 \mathrm{mg} \cdot \mathrm{g}^{-1}$ of total soluble carbohydrate in seeds in physiological maturity.

The high vigor for seeds of cultivar NA 5909 RG in relation to cultivar Benso1RR from non-desiccated plants may be associated with higher initial content of soluble sugar observed for NA 5909 RG in relation to cultivar Benso1RR, and the same was observed by Henning et al. (2010) who claim that soybean seeds with high initial sugar and soluble protein content show high vigor. However, seeds from desiccated plants of cultivar Benso1RR had lower initial content of soluble sugar for dry seeds, showing that the initial content of the reserve components was not the determining factor for the maintenance of the vigor, since there was no difference in vigor between desiccated plant seeds regarding their control for this cultivar.

Seeds germination is a physiological and important process in the development of seedlings, which involves complex processes and the use of their reserves for the formation and establishment of new seedlings (Ishibashi et al., 2013; Kim et al., 2011). During the soaking period in this study, there was a mobilization of soluble sugars and decreases in protein content, indicating the use of these components to form new seedlings. However, there were no significant changes to the phytate content over time. According to Martinez et al. (2011), 48 hours after soaking is a very short period to observe phytate hydrolysis during soybeans seed germination.

The soluble protein content decreased during the soaking time (Figure 3), more sharply for cultivar Benso1RR, with and without desiccation, and for cultivar NA 5909 RG without desiccation, not interfering in vigor. However, for seeds of cultivar NA 5909 RG from desiccated plants, there was a less pronounced mobilization of soluble protein, reflecting at the end of five days in low germination percentages with smaller seedlings and low vigor when compared to control plants seeds.

The lower mobilization of soluble protein over time can be reflected in reduced synthesis of amino acids. According to Han et al. (2013), the increased amino acid content during the germination of soybean seeds is related to protein degradation, which can be translocated to the embryonic axis growing points, thus contributing in forming living tissues and participating in reactions of the respiratory chain.

With 24 hours of soaking, the cultivars from plants control of cultivar NA 5909 RG had lower soluble sugar content

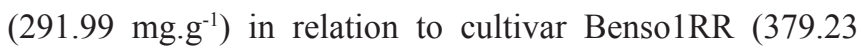
$\mathrm{mg} \cdot \mathrm{g}^{-1}$ ) to issue nearly the same percentage of rootlets, $67 \%$ e $68 \%$, respectively. For seeds from desiccated plants, the differences between cultivars were high, the soluble sugar content for cultivar Benso1RR was $279.27 \mathrm{mg} . \mathrm{g}^{-1}$ with $42 \%$ of root protrusion compared with cultivar NA 5409RG, with soluble sugar content $146.87 \mathrm{mg}^{-1} \mathrm{~g}^{-1}$ and $28 \%$ of root protrusion.

In $48 \mathrm{~h}$ of soaking, when all treatments showed $100 \%$ root protrusion, there was greater mobilization of soluble sugar of cultivar Benso1RR in relation to cultivar NA 5909 RG, both for seeds from control plants as for seeds from desiccated plants (Figure 4). However, when comparing seeds of both cultivars from control plants, cultivar NA 5909 RG (241.44 mg. $\mathrm{g}^{-1}$ ) was more efficient in the use of soluble sugar, because with less mobilization (Figure 4) it showed high vigor in relation to cultivar Benso1RR (365 mg. $\mathrm{g}^{-1}$ ). 


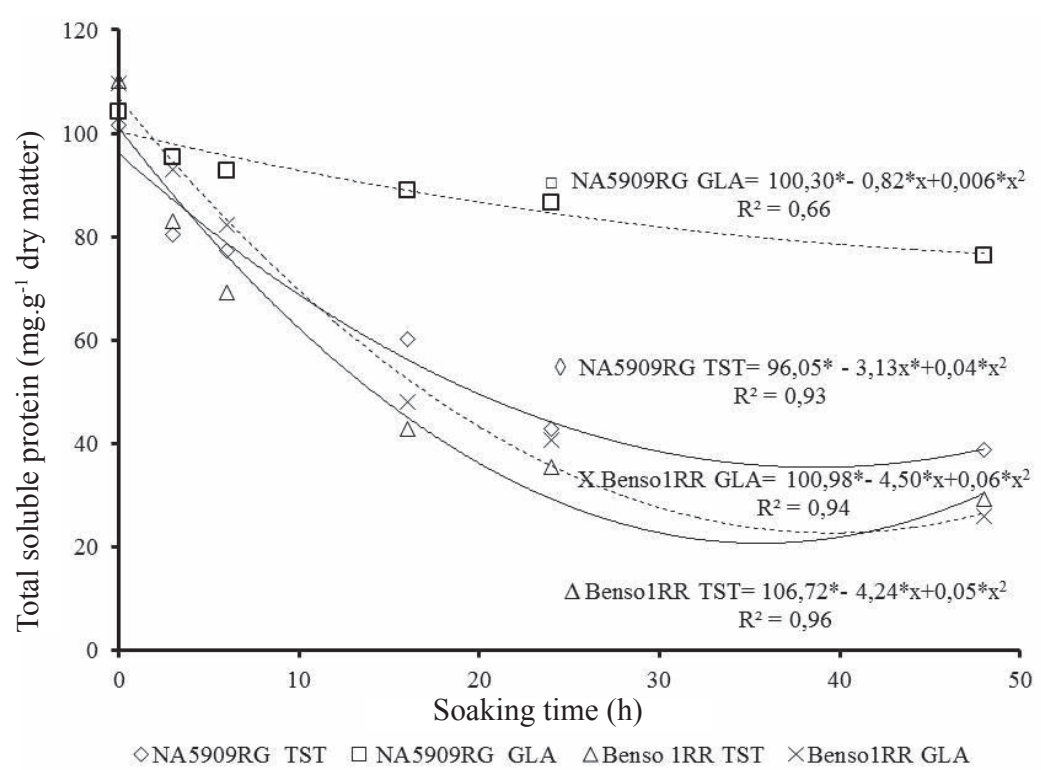

Figure 3. Mobilization of soluble proteins of soybean seeds during germination of cultivars NA 5909 RG and Benso1RR from plants desiccated with glufosinate ammonium (GLA) and non-desiccated (TST). *Significant value $(\mathrm{p}<0.05)-$ Tukey test.

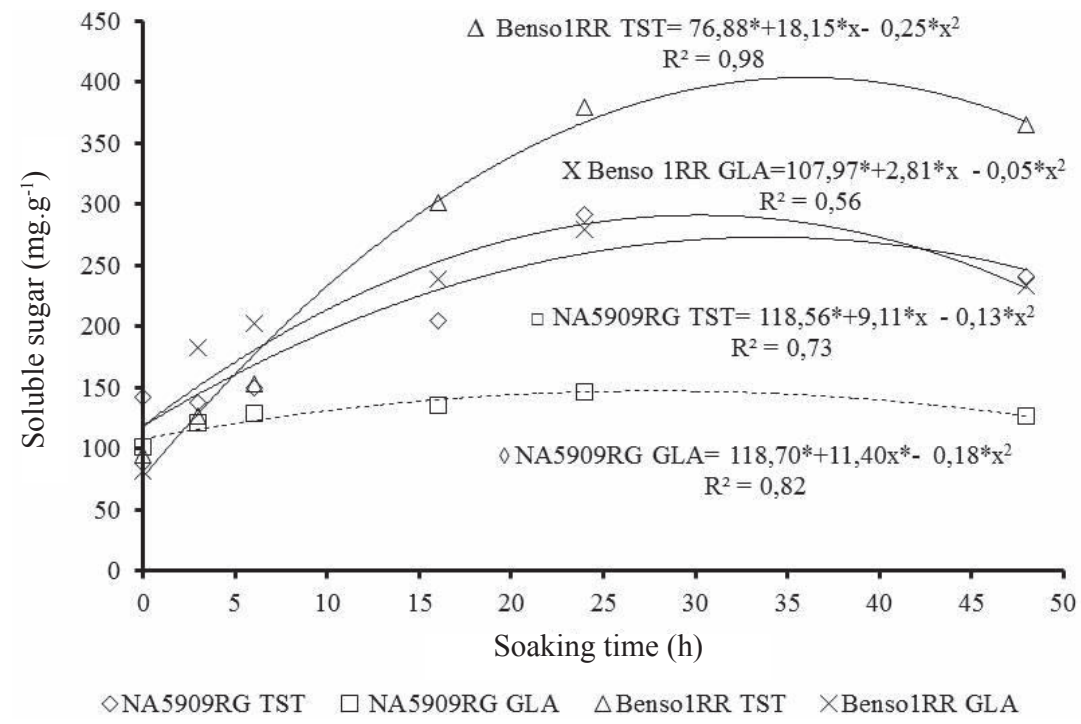

Figure 4. Mobilization of soluble sugar of soybean seeds during seed germination of cultivars NA 5909 RG and Benso1RR from desiccated plants (GLA) and non-desiccated (TST). *Significant value $(\mathrm{p}<0.05)$ - Tukey test.

For seeds from desiccated plants (Figure 4), an opposite behavior was observed, in this case the increased mobilization of soluble sugar of cultivar Benso1RR (233.62 mg.g $\mathrm{g}^{-1}$ ) during soaking because it may have been the determining factor for maintaining vigor and germination percentage on the application of glufosinate ammonium on physiological maturity in relation to cultivar NA 5909 RG (126.98 mg. $\left.\mathrm{g}^{-1}\right)$, and not the higher levels of soluble sugar in the dry seed of cultivar NA 5909 RG in relation to seeds of cultivar Benso1RR.
One possible explanation for glufosinate ammonium having influenced the seeds quality is the presence of the herbicide molecule in the seeds. As this herbicide has the ability to translocate at a short distance, one hypothesis is that it could have crossed the pod and come into contact with the seed, or the product has the ability to change the permeability of the pods membranes, favoring translocation of water and the herbicide molecule itself into the pod, contacting the seed. According to Oliveira et al. (2014), greater absorption 
of water by soybean pods harvested from reproductive stages R7 and R8 takes place, when compared with stages R4, R5 and R6, influencing loss of seed vigor.

Thus, more specific study is being carried out, seeking to understand how the herbicide molecule applied in plants may be affecting the seeds quality and which enzymatic and nonenzymatic mechanisms may be involved in maintaining these seeds vigor, such as, for example, the activity of antioxidant enzymes, non-enzymatic compounds and cellular changes.

\section{Conclusions}

It is concluded that the use of glufosinate ammonium has negatively interfered in the mobilization of reserves for NA 5909 RG, reflecting low vigor and low germination percentage. For cultivar Benso1RR the application of desiccant changed the pattern of water absorption, prolonging phase II of soaking, allowing more time for cellular organization of seeds and mobilization of their reserves, contributing to the maintenance of their vigor.

The use of glufosinate ammonium as a desiccant is not recommended, since for cultivar NA 5909 RG there was a reduction of seed vigor, and for cultivar Benso1RR there was no effective difference between seeds from desiccated plants regarding their control.

\section{Acknowledgments}

To FUMDES program for granting the doctoral scholarship and to CNPq Notice 14, for the financial support granted to project 4818212011-6 and FAPESC (Fundação de Amparo a Pesquisa e Inovação do Estado de Santa Catarina) and $\mathrm{CNPq}$ by productivity grant for second author.

\section{References}

AZEVEDO, R.A.; ALAS, R.M.; SMITH, R.J.; LEA, P.J. Response of antioxidant enzymes to transfer from elevated carbon dioxide to air and ozone fumigation, in the leaves and roots of wild-type and a catalase-deficient mutant of barley. Physiologia Plantarum, v.104, p.280-292, 1998.

BRADFORD, M.M. A rapid and sensitive method for the quantification of microgram quantities of protein utilizing the principle of protein-dye binding. Analytical Biochemistry, v.72, p.248-254, 1976.

BRASIL. Ministério da Agricultura, Pecuária e Abastecimento. Regras para análise de sementes. Ministério da Agricultura, Pecuária e Abastecimento. Secretaria de Defesa Agropecuária. Brasília: MAPA/ACS, 2009. 395p. http:// www.agricultura.gov.br/arq_editor/file/2946_regras_analise_sementes.pdf

CARVALHO, L.B. Dinâmica fisiológica. In: CARVALHO, L.B. Herbicidas, 1 . ed. Lages-SC, 2013. p.21-52.
CASTRO, R.D.; BRADFORD, K.J.; HILHORST, H.W.M. Embebição e reativação do metabolismo. In: FERREIRA, A.G.; BORGHETTI, F. (Orgs.) Germinação do básico ao aplicado. Porto Alegre: Artmed, 2004. p.149-162.

CHENG, L.B.; LI, S.Y.; HE, G.Y. Isolation and expression profile analysis of genes relevant to chilling stress during seed imbibition in soybean [Glycine $\max$ (L.) Merr.]. Agricultural Sciences in China, v.8, n.5, p.521-528, 2009 http://www.sciencedirect.com/science/article/pii/S1671292708602424

CLEGG, K.M. The application of the anthrone reagent to the estimation of starch in cereals. Journal of the Science of Food and Agricultural, v.3, p.4044, 1956.

GARCIA, J.S.; GRATÃO, P.L.; AZEVEDO, R.A.; ARRUDA, M. Metal contamination effects on sunflower (Helianthus annuus L.) growth and protein expression in leaves during development. Journal Agriculture Food Chemistry, v.54, p.8623-8630, 2006. http://www.scielo.br/scielo.php?script=sci nlinks\&ref $=000068 \&$ pid $=$ S0103-9016200800050001500004\&lng $=$ pt

GUIMARÃES, V.F.; HOLLMANN, M.J.; FIOREZE, S.L.; ECHER, M.M.; RODRIGUES-COSTA, A.C.P.; ANDREOTTI, M. Produtividade e qualidade de sementes de soja em função de estádios de dessecação e herbicidas. Planta Daninha, v.30, n.3, p.567-573, 2012. http://www.scielo.br/scielo php?pid=S0100-83582012000300012\&script=sci_arttext

HAN, C.; YIN, X.; HE, D.; YANG, P. Analysis of proteome profile in germinating soybean seed, and its comparison with rice showing the styles of reserves mobilization in different crops. Plos One, v.8, n.2, p.1-9, 2013. http://www.ncbi.nlm.nih.gov/pubmed/23460823

HENNING, F.A.; MERTZ, L.M.; JACOB, E.A.; MACHADO, R.D.; FISS, G.; ZIMMER, P.D. Composição química e mobilização de reservas em sementes de soja de alto e baixo vigor. Revista Bragantia, v.69, n.3, p.727734, 2010. http://www.scielo.br/pdf/brag/v69n3/26.pdf

ISHIBASHI, Y.; KODA, Y.; ZHENG, S.H.; YUASA, T.; IWAYA-INOUE, M. Regulation of soybean seed germination through ethylene production in response to reactive oxygen species. Annals of Botany, v.1, p.1-8, 2013 http://www.ncbi.nlm.nih.gov/pubmed/23131300

KIM, H.T.; CHOI, U.K.; RYU, H.S.; LEE, S.J.; KWON, O.S. Mobilization of storage proteins in soybean seed (Glycine max L.) during germination and seedling growth. Biochimica et Biophysica Acta, v.1814, n.9, p.1178-1187, 2011. http://www.ncbi.nlm.nih.gov/pubmed/21616178

LACERDA, A.L.S.; LAZARINI, E.; SÁ, M.E.; VALÉRIO FILHO, W.V Efeitos da dessecação de plantas de soja no potencial fisiológico e sanitário de sementes. Revista Bragantia, v.64, n.3, p.447-457, 2005a. http://www. scielo.br/pdf/brag/v64n3/26439.pdf

LACERDA, A.L.S.; LAZARINI, E.; SÁ, M.E.; VALÉRIO FILHO, W.V. Armazenamento de sementes de soja dessecadas e avaliação da qualidade fisiológica, bioquímica e sanitária. Revista Brasileira de Sementes, v.25, n.2, p.97-105, 2003b. http://www.scielo.br/scielo.php?pid=S010131222003000400014\&script=sci_arttext

LATTA, M.; ESKIN, M. A simple and rapid method for phytate determination. Journal Agricultural Food Chemistry, v.28, p.313-315, 1980.

MARCOS-FILHO, J. Teste de envelhecimento acelerado. In KRZYZANOWSKI, F.C.; VIEIRA, R.D.; FRANÇA-NETO, J.B. (Ed.) Vigor de sementes: conceitos e testes. ABRATES, 1999. cap.3, p.3.1-3.24.

MA, F.; CHOLEWA, E.; MOHAMED, T.; PETERSON, C.A.; JZEN, M.G. Cracks in the palisade cuticle of soybean seed coats correlate with their permeability to water. Annals of Botany, v.94, p.213-228, 2004. http://aob. oxfordjournals.org/content/94/2/213.full 
MARTINEZ, A.P.C.; MARTINEZ, P.C.C.; SOUZA, M.C.; CANNIATTI BRAZACA, S.G. Alterações químicas em grãos de soja com a germinação. Ciência Tecnologia de Alimentos, v.31, n.1, p.23-30, 2011. http://www.scielo.br/pdf/cta/v31n1/04.pdf

MENGARDA, L.H.G.; LOPES, J.C.A.; RODRIGO, S.A.; ZANOTTI, R.F.; MANHONE, P.R. Alternating temperature and accelerated aging in mobilization of reserves during germination of Carica papaya L. seeds. Journal of Seed Science, v.37, n.1, p.16-25, 2015. http://www.scielo.br/scielo.php?script=sci abstract\&pid=S010131222012000400016\&lng=en\&nrm=iso\&tlng=en

MOREIRA, A.A.; MANDARINO, J.M.G.; NEVES, S.R.D.; LEITE, R.S.; OLIVEIRA, M.A. Teor de ácido fítico em cultivares de soja cultivados em diferentes regiões do Paraná e São Paulo. Alimentos e Nutrição, v.23, n.3, p.393-398, 2012. http://serv-bib.fcfar.unesp.br/seer/index.php/alimentos/ article/viewFile/393/2047

NAKAGAWA, J. Testes de vigor baseados no desempenho das plântulas. In: KRZYZANOWSKI, F.C.; VIEIRA, R.D.; FRANCA-NETO, J.B. (Ed.). Vigor de sementes: conceitos e testes. Londrina: ABRATES, 1999. p.2.1-2.24.

OBENDORF, R.L.; ZIMMERMAN, A.D.; ZHANG, Q.I.; CASTILLO, A.; KOSINA, S.M.; BRYANT, E.G.; SENSENING, E.M.; WU, J.; SHNEBLY, S.R. Accumulation of soluble carbohydrates during seed development and maturation of low-raffinose, low-stachyose soybean. Crop Science, v. 49, p.329 - 341, 2009. https://www.crops.org/publications/cs/abstracts/49/1/329

OLIVEIRA, C.M.G.; KRYZANOWSKI, F.C.; OLIVEIRA, M.C.N.; FRANÇA-NETO, J.B.; HENNING, A.A. Relationship between pod permeability and seed quality in soybean. Journal of Seed Science, v.36, n.3, p.273-281, 2014. http://www.scielo.br/pdf/jss/v36n3/aop0214.pdf

PEREIRA, W.A.; PEREIRA, S.M.A.; DIAS, D.C.F.S. Dynamics of reserves of soybean seeds during the development of seedlings of different commercial cultivars. Journal of Seed Science, v.37, n.1, p.63-69, 2015. http://www. scielo.br/pdf/jss/v37n1/2317-1537-jss-37-01-00063.pdf
PINTO, M.A.B.; BASSO, C.J.; KULCZYNSKI, S.M.; BELLE, C. Productivity and physiological quality of seeds with burn down herbicides at the preharvest of bean crops. Journal of Seed Science, v.36, n.4, 384-391, 2014. http://www.scielo.br/pdf/jss/v36n4/aop0814.pdf

RITCHIE, S.; HANWAY, J.J.; THOMPSON, H.E. How a soybean plant develops. Ames: Iowa State University of Science and Technology, 1982. 20p.

SAS. SAS Institute Inc ${ }^{\circledR} 2009$. Cary, NC, USA, Lic. UDESC: SAS Institute Inc, 2009.

SCOTT, J.J. Alkaline phytase activity in nonionic detergent extracts of legume seeds. Plant Physiology, v.95, n.1, p.1298-1301, 1991

STAJNER, D.; MILOŠEVIĆ, M.B.; POPOVIĆ, M. Irradiation effects on phenolic content, lipid and protein oxidation and scavenger ability of soybean seeds. International Journal of Molecular Sciences, v.8, p.618-627, 2007. http://www.mdpi.org/ijms/papers/i8070618.pdf

TEULAT-MERAH, B.; MORERE-LE PAVEN, M.C.; RICOULT, C.; AUBRY, C.; PELTIER, D. cDNA-AFLP profiling in the embryo axes during common bean germination. Biologia Plantarum, v.55, n.3, p.437-447, 2011. http://link.springer.com/article/10.1007/s10535-011-0108-5

WEITBRECHT, K.; MÜLLER, K.; LEUBNER-METZGER, G. First off the mark: early seed germination. Journal of Experimental Botany, v.62, n.10, p.3289-3309, 2011. http://www.ncbi.nlm.nih.gov/pubmed/21430292 